above case was neither phthisical nor a hamophiliac. There is strong evidence to prove that the disease was conveyed through the milk-supply coming from an infected house where there were four cases of typhoid fever. The milk was not boiled before use, and a second inmate of the patient's house also contracted enteric fever. Some others to whom the milk had been supplied were protected by previous attacks; in other cases the milk was regularly boiled. In these latter no bad results have appeared as yet, a point in favour of the advisability of boiling milk.

Ookiep, Cape Colony.

\section{THE MORTALITY FROM EMPYEMA IN CHILDHOOD.}

BY J. P. WIGHTMAN, M.R.C.S. ENG., L.R.C.P. LOND.,

IATE SENIOR HOUSE SURGEON, INFIRMARY FOR CHILDREN, LIVERPOOL.

IN this condition, a serious and not uncommon one, a favourable prognosis may be given, providing that the diagnosis is made in the early stages. What can be more sad than a mother bringing her child, worn out by prolonged hectic due to a discharging empyema, for advice? The rapidity of convalescence, averaging from six to eight weeks, and the usual cure, no trace of the disease remaining, add a special attraction to a condition which, if left alone, must almost always produce a fatal result. The subject of this disease and its treatment has been brought forward in the various medical journals, this paper being in part a résumé of the various views and methods of treatment.

Signs of a recent attack of scarlet fever (desquamation \&c.) are by no means uncommon in patients seeking relief at a children's hospital. With regard to this, it is remarkable that among 1008 cases of scarlet fever, mostly in children, recorded in 'l'HE LANCET during the year 1891 empyema is not even mentioned as a complication; nor is this the case in a paper on Scarlet Fever published in Vol. XXI. of the St. Thomas's Hospital Reports. This naturally leads one to infer that empyema is most likely to occur if a case of scarlet fever is neglected. Various statistics of mortality are on record. The younger the patient the greater the risk of a fatal termination. The sooner the purulent effusion is removed the quicker the recovery. Rupture of an empyema through the chest wall or into the lung is a grave complication, though the latter occasionally leads to spontaneous cure. Apart from the above, danger to life is chiefly threatened by the onset of complications-viz.: (1) pericarditis (among 29 fatal cases ai the Liverpool Children's Infirmary ${ }^{1}$ pericarditis occurred 12 times, in 10 it was of the suppurative form); (2) peritonitis; and (3) septicæmia.

As regards the effect that different methods of treatment have, taken as a whole, I do not think resection of rib renders the chance of cure either greater or less, except in certain cases. At the Hospital for Sick Children, Great Ormondstreet, from 1880 to 1892 , 214 cases were treated. Of these, 85 were treated during the earlier period by incision, with 16 deaths, and 129 afterwards by resection of rib, with 23 deaths, the mortality, as will be seen, being nearly the same in each case. ${ }^{2}$ Mr. Godlee published in 1886 the result of 36 cases. The majority (19) were treated by resection, the remainder by incision or aspiration. Of these cases only 1 was fatal. In THE LANCET of May 5th, 1894, I published the results of 118 cases, classifying all treatments together, with 23 deaths. In the same journal ${ }^{3}$ Dr. F. E. Batten of London published the results at the Hospital for Sick Children, Great Ormond-street, for the year 1893-94. Of 43 cases treated by resection, 5 were fatal. In THE LANCET also he asserts strongly that resection is the only treatment for empyema, a statement which I think cannot be accepted without much reserve. Dr. E. Cautley of London, at a meeting of the London Medical Society, ${ }^{4}$ in a paper based upon a series of 86 cases treated by various methods, gave a mortality of 16.6 per cent. The rate of mortality was the same after resection as after incision, with the exception that 5 out of 6 cases under two years old, treated by resection, were fatal. His opinion was

1 The Lancer, May 5th, 1894.
2 Mr. Bernard Pitts : The LANCET, Sept. 9th, 16th, 23rd, and 30th, and 0ct. 14th, 1893

3 THE Laycer', June 2nd, 1894.

4 Tere Lancet, Feb. 2nd, 1895. that resection ought only to be had recourse to in cases in which the tube could not be inserted without, when drainage was imperfect, or for the cure of an old sinus. Dr. Morison of Hartlepool (34 cases, 2 deaths) upholds incision. ${ }^{5}$ By the courtesy of Mr. Jordan Lloyd of Birmingham I am able to publish the treatment and results at the Birmingham and Midland Children's Hospital for the last five years. The total number of cases treated was 123 ; of these, 99 were cured, 20 were fatal, and of 4 there are no records. Among children of three years of age and under there were 43 cases; of these, 18 ended fatally. In the 99 cases cured the average stay in hospital was seven weeks and a half, the shortest stay eleven days, and the longest 164 days. Resection of rib was performed in 6 cases. I am indebted to $\mathrm{Mr}$. $\mathrm{H}$. G. Davis, house surgeon of the hospital, for taking much trouble in the preparation of the hospital statistics.

The rontine treatment is incision and drainage as soon as pus is determined. Resection of rib is exceptional as a primary procedure.

If the above figures are put together they number 656 cases of empyema in children, with 104 deaths, giving a death-rate of 16 per cent.

The extreme gravity of empyema in a young child may be seen by the following :-

\section{Mortality from Empyema in Children three years old} and under.

Dr. Goodhart (Guy's Hospital Reports)... Cases. Deaths. .

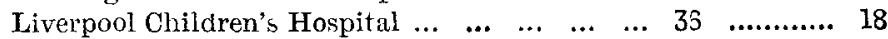

These figures give a death-rate of a little over 50 per cent. Rawdon, Leeds.

\section{a dittror} OF

\section{H O P I T A L P R A C T I C E, BRITISH AND FOREIGN.}

Nulla autem est alia pro certo noscendi via, nisi quamplurimas et morborum et dissectionum historias, tum aliorum tum proprias collectas habere, et inter se comparare.-MoRGAGNI De Sed. et Caus. Morb.. habere, et inter so

\section{ROYAL FREE HOSPITAL.}

CHRONIC RIGHT-SIDED THE SUPERIOR VENA CAVA SMUTATING INTRA-THORACIC TUMOUR; REMARKS.

(Under the care of Dr. H. SAlnsBURY.)

THE symptoms to which malignant growths of the chest give rise are very variable, depending upon the starting-point of the disease, whether pleura, bronchial tubes, or lung tissue. As these symptoms may be for a long time only those of a simple inflammation of the part attacked, this difficulty in diagnosis will be readily appreciated. The results which inflammation in its several stages and manifold incidence may bring about constitute an almost infinite variety of combinations. Here is an instance in which the diagnosis of intra-thoracic tumour, probably new growth, was made with some confidence, and yet the result of the post-mortem examination proved this to have been a mistake. The changes produced by the inflammation were unusual and extensive, but they were in no way the result of tumour formation.

A woman aged sixty-two was admitted into the Royal Free Hospital on Nov. 22nd, 1894, suffering from dyspnoea (of the variety orthopnœa), with much cyanosis and cough. She stated that she had suffered from winter cough for some years, that her present cough had been worse since the taking of a chill some six weeks before admission, and that her breath had become very short, especially of late. Two weeks before entering the hospital she said that she had noticed some blood mixed with the expectoration. Since the chill-i.e., during a period of six weeks-she was conscious of having wasted and lost strength. On examination the evidence of fluid in the right pleura was found but though the chest on the right side was dull and 
resisting from top to bottom both back and front, the position of tho heart's apcx boat showed little, if any, sign of displacement of the mediastinum. The liver eclge was felt well below the costal margin, but upon this as a sign of depressed diaphragm one could, of course, not rely. Accordingly the dulness in degree and extent seemed to be in excess of that which an effusion could account for. The cyanosis mentioned was marked and accompanied by a pronounced anastomotic enlargement of the veins over the anterior surface of the trunk. Clearly there was obstruction of the superior vena cava. The chest was tapped and a small quantity of dark, sanguineous fluid withdrawn. The quantity which came away, under fiftcen ounces, was wholly inadequate to relieve a distended pleura, but it was all that would flow off by syphon action, and, under the circumstances, all it was thought wise to try to get. The relief obtained was but slight, and in the course of a week or ten days paracentesis was again performed, with a similar result, but a rather smaller withdrawal ; the fluid removed had the same dark, sanguineous character. The dyspncea and cyanosis increased, the patient grew progressively weaker, and she died on Dec. 22nd, one month after her admission. Throughout her stay in hospital the temperature curve was apyrexial. There is nothing of importance to add in the way of history. The patient had scarlet fever when aged fifteen years and rheumatic fever when aged twenty. The family history threw no light on the case. At the necropsy, which was held on Dec. $24 \mathrm{th}$, the right pleural sac was found to be converted into a cavity with thickened, rigid, almost cartilaginous walls, in which the same sanguineous fluid was found which on two occasions had been withdrawn in small quantity. Both layers of the pleura, parietal as well as visceral, were equally affected, and the mediastinum towards its dexter aspect shared in the thickening. The right lung pressed upwards,

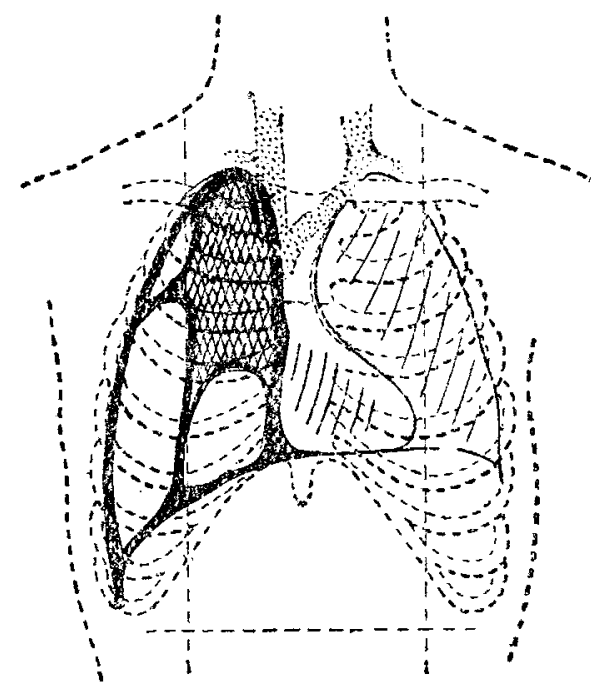

inwards, and backwards, and, occupying perhaps one-third or one-fourth of its normal dimensions, was tied at two or more spots to the parietal pleura by stout cord-like processes of cartilaginous consistence. Towards the apex, in the vertebral groove and against the upper half of the mediastinum, the lung was adherent. Tracing the large veins from the root of the neck downwards into the chest, their dilated channels were found to maintain their patency till at their confuence in the superior vena cava where they entered the mediastinal thickening. The constriction here was such that the channel was reduced to a narrow, slit-like aperture admitting about a No. 5 catheter. Nothing in the shape of a tumour was discovered, and the mediastinal sclerosis causing the constriction was exactly similar in character to, and in mo sense demarcated from, the general pleural thickening. The rigid-walled right pleural cavity could not have been under any tension from the fluid it contained, and it is more than probable that the exudation was a passive one from the congested intercostal veins, which followed, but scarcely pressed upon, the receding lung, as its thickened capsuje (peripulmonitis) contracted upon the lung sponge work. 'The reason for the inadequate tappings now became quite evident: it would have been as feasible to drain a full beer barrel without a rent-peg as to empty this cavity by single aspirating puncture. No disease was found in the camified tissues of the right lung, but the expanded left lung, which projected slightly across the micmine, showed a hard knot on the outer si,rface of its upper lobe, with some surroundiog pucker* ing; there was no careous centre to it.

liemarks by Dr. SAINsBuRY.-It may be well to summarise the chief points upon which the cliagnosis in the above case rested; they wcre the age of the patient, the latency of origin of the symptoms or their insidious onset, the accom. panying loss of flesh and strength, the presence on at least one occasion of some blood in the expectoration, the dulness in excess of the eviclence of fluid, the sanguineous character of the exudation, and, above all, the evidence of intrathoracic local obstruction to the venous circulation. This group seemed to warrant the conclusion which was arriced at-viz., intra-thoracic tumour, probably malignant, with secondary implication of the pleura. Dr. Walsbe, I am told, used to say on occasion that he had given up guessing; he probably did not mean this; but, face to face with the innumerable possible combinations of disease, even a shrewc guess may at times hardly be hazarded.

\section{NORTH-EASTERN FEVER HOSPITAL.}

A CASE OF SCARLET FEVER; OTORPHCEA; THROMBOSIS OF 'IHE LA'IERAL SINUS; PYAMIA AFWECTING RIGH'I LLBOW AND ILEFI HIP; RECOVERY.

(Under the care of Dr. F. M. TuRNer.)

SEYERAL cases lave been recorded during recent months of septic thrombosis of the lateral sinus occurring during an attack of acute suppurative otitis media. As a rule in such cases there is a history given of a chronic discharge from the ear. or of an offensive smell which is found to depend on oldstanding disease without the escape of an appreciable quantity of discharge. In this case operation was required within a month after the discharge commenced. It is also remarkable for the few signs which were present at the time of the operation on the sinus, more especially the ab-ence of any swelling, fulness, or tenderness over the jugular vein in the neck, although there was an increase of discharge from the opening in the bone on pressure over the ressels. There can, we think, be little doubt that the suppuration in the joints was pyamic and resulted from the ear complication. The suppurative arthritis of scarlet fever usually shows itself about the third or fourth week, and although in more than one of the fatal cases thrombosis of the internal jugular vein has been noted it has not resemblec that which is described here. The pain in the mastoid preceded the rigor, and the joint complications appeared the day after the operation, possibly caused by disturbance of clot during the necessary manipulations. The advantages of early incision of the joints are shown by the result. There is no doubt that a free incision with washing out is the best treatment for a pyæmic joint, and that harm is done by delay.

A slight]y built boy aged six years was admitted to the North-Eastern Fever Hospital on Jan. 31st, 1895, suffering from scarlet fever. He developed the first symptoms on Jan. 27th, and the rash on the following day. During the whole of February he remained in a very serious condition, with a foul throat, swollen cervical glands, a nearly continuous high temperature, a small amount of albumin in the urine, and great muscular weakness. He became extremely emaciated though he took a fair quantity of fluid food. Feeding was very troublesome owing to his bad throat, but forced feeding through a tube did not become necessary. Otorrhoea developed on the right side on Feb. 8th, and on the left a few days later. Towards the end of the month his temperature was rather lower, but very irregular. On the 26 th it remained below $100^{\circ} \mathrm{F}$. the whole day, and Dr. Turner thought he had slightly improved in strength and seemed more comfortable. On March 2nd, however, the temperature again rose to $104^{\circ}$, and he vomited three times. He complained of pain in his right ear; he had hardly spoken a word the whole time he had been in hos. pital, and this was the first occasion he gave any useful information. Two days later he had a rigor lasting ten ninutes, with a temperature of $104 \cdot 8^{\circ}$. The pupils were unequal and remained so for some weeks later. The optic dises were normal, and there was no further vomiting. The diagnosis lay between two diseases, either of which would produce the symptoms observed: (1) acute interstitia nephritis or septic nephritis, a form which frequently accompanies the cases of scarlet fever complicated with 